\title{
Effect of salinity stress on the life history variables of Branchipus schaefferi Fisher, 1834 (Crustacea: Anostraca) SSS Sarma*1, Lynda Beladjal ${ }^{2}$, S Nandini ${ }^{3}$, Gerardo Cerón-Martínez ${ }^{1}$ and Karina Tavera-Briseño ${ }^{1}$
}

\begin{abstract}
Address: 'Laboratory of Aquatic Zoology, UMF, Division of Research and Postgraduate Studies, National Autonomous University of Mexico, Campus Iztacala, Av. de los Barrios S/N, Los Reyes, AP 314, CP 54090, Tlalnepantla, State of Mexico, Mexico, ${ }^{2}$ Laboratory of Animal Ecology, Ghent University, Ledeganckstraat 35, B-9000 Gent, Belgium and ${ }^{3}$ UIICSE, Division of Research and Postgraduate Studies, National Autonomous University of Mexico, Campus Iztacala, Av. de los Barrios S/N, Los Reyes, AP 314, CP 54090, Tlalnepantla, State of Mexico, Mexico

Email: SSS Sarma* - sarma@servidor.unam.mx; Lynda Beladjal - Lynda.Beladjal@rug.ac.be; S Nandini - nandini@servidor.unam.mx; Gerardo Cerón-Martínez - Lynda.Beladjal@rug.ac.be; Karina Tavera-Briseño - nandini@servidor.unam.mx

* Corresponding author
\end{abstract}

Published: 04 July 2005

Saline Systems 2005, I:4 doi:10.1 186/1746-1448-1-4

This article is available from: http://www.salinesystems.org/content/I/I/4

(C) 2005 Sarma et al; licensee BioMed Central Ltd.

This is an Open Access article distributed under the terms of the Creative Commons Attribution License (http://creativecommons.org/licenses/by/2.0), which permits unrestricted use, distribution, and reproduction in any medium, provided the original work is properly cited.
Received: 26 April 2005

Accepted: 04 July 2005

\begin{abstract}
Background: Freshwater anostracans inhabit ephemeral water bodies in which as the water level decreases due to evaporation the salt concentration increases. Thus, for most anostracans salinity becomes the major stress factor.

Results: We tested five concentrations of $\mathrm{NaCl}(0$ to $8 \mathrm{~g} / \mathrm{l})$ on the life table demography of Branchipus schaefferi fed Chlorella (alga). Age-specific survivorship curves of male and female $B$. schaefferi showed nearly a similar pattern in that increased salt concentration resulted in decreased survivorship. The age-specific reproduction $\left(m_{x}\right)$ of females showed several peaks of cyst production at 0 and $\mathrm{I} g / \mathrm{l}$ salinity while in treatments containing salt at 4 or $8 \mathrm{~g} / \mathrm{l}$, there were fewer peaks. Average lifespan, life expectancy at birth, gross and net reproductive rates, generation time and the rate of population increase were all significantly influenced by the salt concentration in the medium. The highest value of net reproductive rate (970 cysts/female) was in treatments containing $0 \mathrm{~g} / \mathrm{l}$ of salt, while the lowest was 13 cysts/female at $8 \mathrm{~g} / \mathrm{l}$. The rate of population increase $(\mathrm{r})$ varied from 0.52 to 0.32 per day depending on the salt concentration in the medium.
\end{abstract}

Conclusion: The low survival and offspring production of $B$. schaefferi at higher salinity levels suggests that this species is unlikely to colonize inland saline water bodies. Therefore, the temporary ponds in which it is found, proper conservative measures must be taken to protect this species.

\section{Background}

Freshwater anostracans usually inhabit ephemeral waterbodies, which periodically dry, especially during summer months. This condition forces them to adapt to a) mostly one population cycle, b) produce cysts that resist desiccation and c) survive under changing ionic composition of the ambient medium [1]. The ionic composition of freshwater bodies is controlled by many factors. Among abiotic factors, temperature, through evaporation, plays an important role. Usually as the water level decreases due to evaporation, salt concentration increases. Therefore, both flora and fauna of such waterbodies must show some 
degree of salt tolerance in order to survive [2]. Knowledge on the pond salinity effects on the osmoregulation and conformation of anostracans is much limited. For example, Branchinecta gigas Lynch, 1937 and B. mackini Dexter, 1956 from saline lakes in Central Washington revealed that both these species have the capacity of hyperosmoregulation during low saline conditions and osmoconformation during high salinity conditions [3]. On the other hand, Branchinella compacta Linder, 1941 occurs in low saline conditions and has less tolerance to high salinity [4]. Thus, it remains unknown the tolerance capacities of many anostracan species.

Freshwater anostracans can survive during the drying period, yet their tolerance to increased salt levels is not well documented [1]. Mere survival under a given natural stress is not adequate for the continuation of a species; the reproductive output too is important. Thus, the reproductive strategies of freshwater anostracans reveal the vicissitudes of their habitat [5]. For most freshwater organisms including crustaceans, salinity is a major stress factor [6]. Increase in salinity leads to reduced survival, reduced reproductive output or both. For a given freshwater species, at salt concentrations below the median tolerance limits, reproduction is more drastically affected than survival or other variables such as swimming speed or the feeding rate [7].

The life history characteristics of crustaceans, in general, are best understood using life table demographic studies [8]. The variables more sensitive to stress are a) average lifespan, b) life expectancy at hatching, c) gross reproductive rate and d) net reproductive rates, e) generation time and $f$ ) the rate of population increase. However, not all variables are consistently sensitive to the same stress. Usually, the rate of population increase is thought to be more sensitive than the rest of the life history variables since it integrates both the mortality and natality [9]. Similar trends may be found in freshwater anostracans to salinity, but quantitative data are lacking for many genera except Artemia [10].

The aim of the present work was to evaluate the effect of different concentrations of sodium chloride on the life table demography of the freshwater anostracan Branchipus schaefferi Fisher, 1834.

\section{Results}

\section{Survivorship curves}

Age-specific survivorship curves (Fig. 1) of female (A) and male (B) B. schaefferi showed a nearly similar pattern in relation to salt concentration (from $0 \mathrm{~g}$ to $8 \mathrm{~g} / \mathrm{l}$ ). At the highest salt concentration $(8 \mathrm{~g} / \mathrm{l})$, females continued to live without mortality for the first week. The age-specific reproduction $\left(\mathrm{m}_{\mathrm{x}}\right)$ (Fig. 2) of females showed several peaks of cyst production at 0 and $1 \mathrm{~g} / \mathrm{l}$ salinity while in treatments containing 4 or $8 \mathrm{~g} / \mathrm{l}$, there were fewer peaks.

\section{Life history variables}

All the selected life history variables of $B$. schaefferi were significantly affected at even the lowest salinity increase (Table 1). Life expectancy at birth of males in $0 \mathrm{~g} / \mathrm{l}$ salinity was slightly higher than females. However, in treatments containing a certain concentration of $\mathrm{NaCl}$, this was nearly similar for both sexes. Also, regardless of sex, increased concentration of salt in the medium decreased the life expectancy. At the highest salt concentration, the life expectancy was nearly $1 / 6$ th of the controls $(0 \mathrm{~g} / \mathrm{l})$. Gross and net reproductive rates also decreased with increasing salt level in the medium. The highest net reproductive rate ( 970 cysts/female) was in treatments containing $0 \mathrm{~g} / \mathrm{l}$ salt, while the lowest (13 cysts/female) at $8 \mathrm{~g} / \mathrm{l}$.

The rate of population increase $(\mathrm{r})$ varied from 0.52 to 0.32 depending on the salt concentration in the medium. As in the case of other survivorship variables, $r$ decreased with an increase in $\mathrm{NaCl}$ in the medium. Generation time varied from 8 to 25 days, depending on the salt concentration. There was a positive relation between average lifespan and the generation time of B. schaefferi (Fig. 3).

Statistically, all the tested variables (survivorship variables: average lifespan, life expectancy at birth, reproductive variables: gross and net reproductive rates, generation time and the rate of population increase) were significantly influenced by the salt concentration in the medium ( $p<0.001$, one-way ANOVA). Tukey's tests revealed that all the above variables at $0 \mathrm{~g} / \mathrm{l}$ salinity were significantly different $(\mathrm{p}<0.05)$ from the treatments containing some quantity of $\mathrm{NaCl}$. However, reproductive variables at 2, 4 and $8 \mathrm{~g} / \mathrm{l}$ were not significantly different $(\mathrm{p}>0.05)$.

\section{Discussion}

Anostracans are particularly well suited for studying the impact of salt concentrations on the life history characteristics because they live in aquatic environments with a continually changing ionic composition [11]. Consequently, within its lifespan, an individual experiences different salinities, which in turn may affect the survival and reproductive performance [5].

Many species of freshwater anostracans feed on green algae [1]. Branchipus schaefferi was earlier cultured on the green agla Scenedesmus [12], which suggests that the use of algal diet was adequate for both survival and reproduction. This was evident in our study too, where in the absence of salt stress, $B$. schaefferi was able to survive and reproduce cysts. 


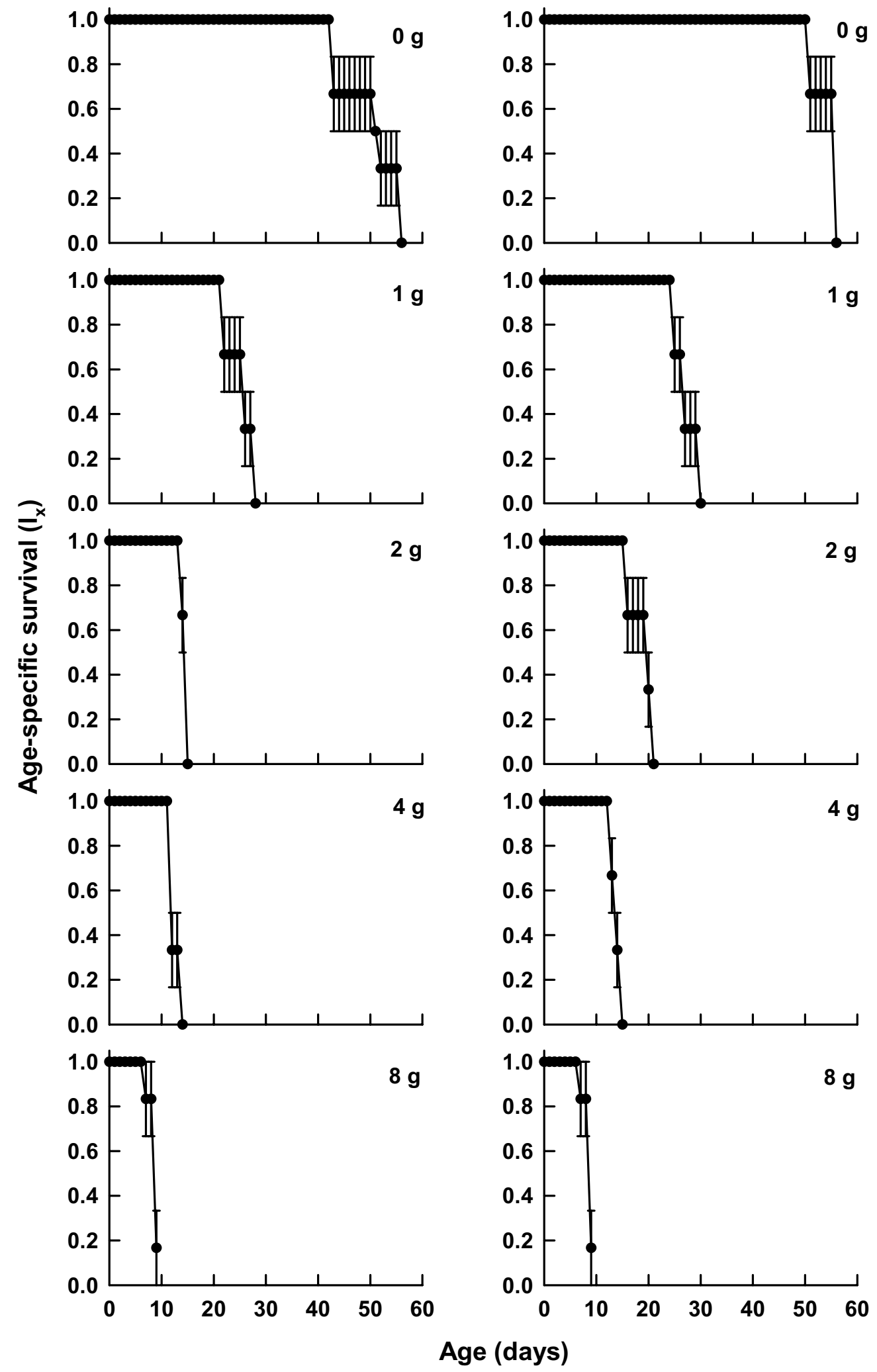

Figure I

Age-specific surviorship $\left(I_{x}\right)$ curves of $B$. schaefferi subjected to different concentrations of $\mathrm{NaCl}$. Column $A$ : female; Column $B$ : male. Values represent mean \pm standard error based on 3 cohorts. 


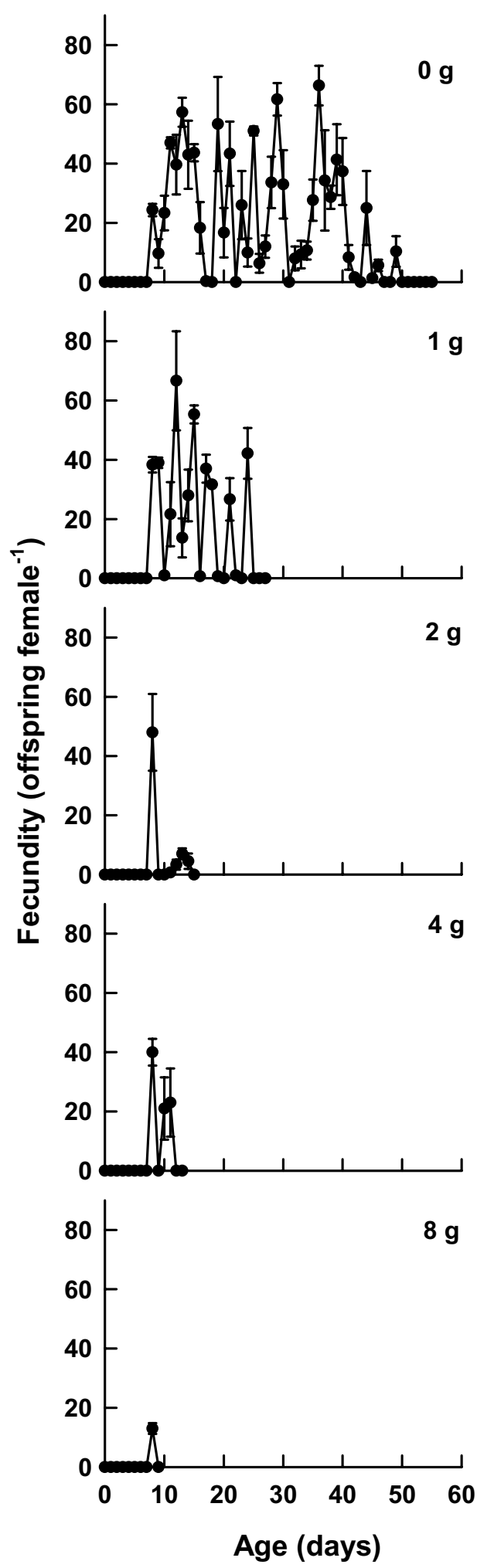

Figure 2

Age-specific fecundity $\left(m_{x}\right)$ curves of female $B$. schaefferi subjected to different concentrations of $\mathrm{NaCl}$. Values represent mean \pm standard error based on 3 cohorts.
Temporary waterbodies are characterized by opportunitistic species including anostracans. High reproductive output, short lifespan and wide diet breadth are some of the characteristics of crustacean species inhabiting temporary waters $[2,5]$. Many species of freshwater anostracans have a lifespan varying from about two weeks to several months [1]. In the present study, regardless of salt concentration, the maximum lifespan varied from 10 to 55 days. Compared to a previous study on the same species [13], the maximum lifespan in this study was slightly shorter (55 vs 77 days). However, as documented earlier, both males and females had nearly the same lifespan [13]. Depending on the environmental conditions, the age-specific life survivorship curves of anostracans may be type I (low initial mortality), type II (mortality rate independent of the age) or type III (heavy initial mortality) [14]. Usually under stressful conditions, the age-specific survivorship curves tend to be type III [15]. Increase in salt concentration in this study was a stress for $B$. schaefferi and therefore, with increasing $\mathrm{NaCl}$ level in the medium, there was steep fall in the survivorship in the initial age groups. Salt levels as low as $1 \mathrm{~g} / \mathrm{l}$ caused about $80 \%$ mortality within 30 days for both males and females. At $8 \mathrm{~g} / \mathrm{l}$, both males and females lived for about a week without mortality and thereafter the survival rapidly declined.

Variable (saw tooth-like) cyst production is characteristic of crustaceans including anostracans that live more than 2 months $[14,16]$, where offspring production is pulsed, i.e., after 5-10 day intervals neonate production peaks and during the interim period fewer eggs are produced. In B. schaefferi too, in treatments containing no salt or $1 \mathrm{~g} / \mathrm{l}$ level, the offspring production was pulsed. With increased salinity in the medium fewer offspring were produced suggesting that salt levels beyond $2 \mathrm{~g} / \mathrm{l}$ are highly stressful for $B$. schaefferi. The maximum cysts per brood was about 70. Reproduction was extremely low at $8 \mathrm{~g} / \mathrm{l}$. The number of cysts per brood for Streptocephalus may be as high as 900; however under inappropriate conditions this number may be as low as 1 cyst/brood [17]. In our study, the peak cyst production per brood was $<20$ at the highest salinity $(8 \mathrm{~g} / \mathrm{l})$. When cultured on a diet of Scenedesmus at a density of $1 \times 10^{6}$ cells $/ \mathrm{ml}$, the maximum number of cysts per brood of $B$. schaefferi was 192 [13]. In the present study, this was much lower. This was probably due to the food density used. Based on dry weight [18], the quantity of algal diet used by Beladjal et al. [13] was nearly twice that used in this study. There is abundant evidence that increase in algal density increases the cyst production in anostracan species [1]. Generation time and rate of population increase observed for $B$. schaefferi are in broad agreement with those reported for freshwater anostracans [14]. 
Table I: Selected life history variables of Branchipus schaefferi exposed to different concentrations of salt. For a given variable, treatments carrying same alphabet are not statistically significant ( $p>0.05$, Tukey's test)

\begin{tabular}{|c|c|c|c|c|}
\hline $\begin{array}{l}\text { Salt conc. } \\
(g / l)\end{array}$ & $\begin{array}{l}\text { Life Expectancy at birth } \\
\text { (days) }\end{array}$ & $\begin{array}{l}\text { Gross Reproductive rate } \\
\text { (cysts / female) }\end{array}$ & $\begin{array}{l}\text { Net reproductive rate } \\
\text { (cysts / female) }\end{array}$ & $\begin{array}{l}\text { Rate of pop. increase } \\
(r)\end{array}$ \\
\hline & Female & & & \\
\hline 0 & $49.5 \pm 1.9 a$ & $990.8 \pm 47.0^{a}$ & $969.7 \pm 37.4^{\mathrm{a}}$ & $0.515 \pm 0.004^{a}$ \\
\hline I & $24.8 \pm 0.8^{b}$ & $412.3 \pm 14.6^{b}$ & $395.0 \pm 20.9 b$ & $0.542 \pm 0.002^{b}$ \\
\hline 2 & $14.2 \pm 0.2^{c}$ & $63.5 \pm 6.9 c$ & $62.0 \pm 8.1^{c}$ & $0.480 \pm 0.003 c$ \\
\hline 4 & $12.2 \pm 0.3^{c, d}$ & $84.0 \pm 24 . I^{c, d}$ & $84.0 \pm 24 . I^{c}$ & $0.490 \pm 0.02^{c}$ \\
\hline \multirow[t]{2}{*}{8} & $8.5 \pm 0.1^{d}$ & $13.0 \pm 1.8^{\mathrm{d}}$ & $13.0 \pm 1.8^{c}$ & $0.318 \pm 0.0 I^{c}$ \\
\hline & Male & & & \\
\hline 0 & $53.8 \pm 1.7 \mathrm{a}$ & & & \\
\hline 1 & $26.8 \pm 1.4^{b}$ & & & \\
\hline 2 & $18.5 \pm 1.5^{c}$ & & & \\
\hline 4 & $14.5 \pm 0.2^{\mathrm{d}}$ & & & \\
\hline 8 & $8.3 \pm 0.2^{\mathrm{e}}$ & & & \\
\hline
\end{tabular}

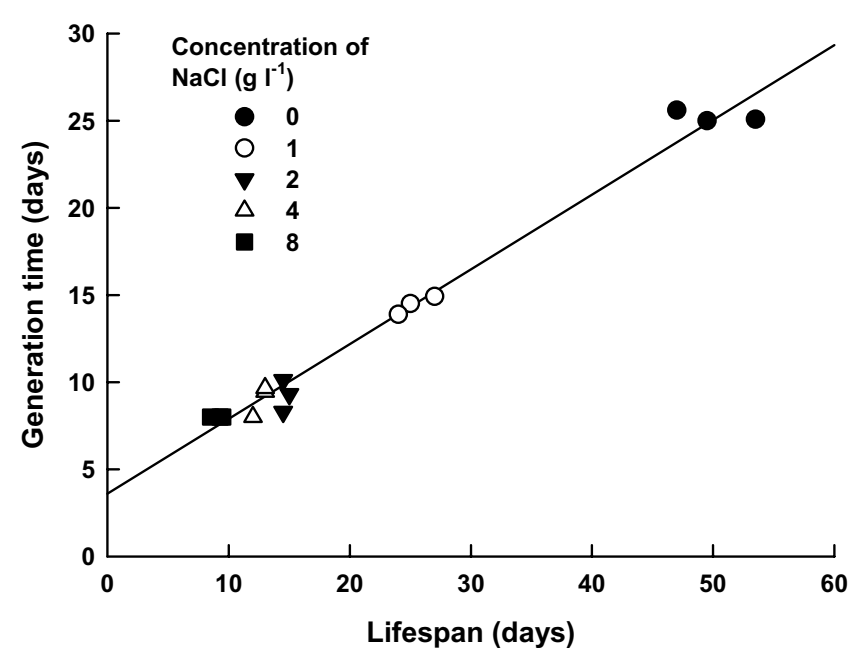

Figure 3

Relation between average lifespan and generation time in $B$. schaefferi under different concentration of $\mathrm{NaCl}$. Plotted are the replicated data for each treatment.

Interrelationships exist among different life history variables of organisms. For example, body size and clutch size relation in crustaceans is generally positive and linearly or curvilinearly related [19]. Similarly generation time and lifespan are linearly related for many species of zooplankton such as rotifers [20], cladocerans [19], a few anostracans (e.g., Streptocephalus mackini Moore, 1966) [14] and now also in B. schaefferi.

The low tolerance capacity of $B$. schaefferi to $\mathrm{NaCl}$ as observed in the present study is also confirmed from field observations. For example, Maier et al. [11] have reported the occurrence of $B$. schaefferi in man-made freshwater bodies in Germany. However, with an increase in conductivity (higher than $300 \mu \mathrm{S} / \mathrm{cm}$ which is equivalent to $<0.5$ $\mathrm{g} / \mathrm{l})$, B. schaefferi was almost eliminated. There are also some differences with reference to the ionic composition of water in naturally drying ponds and $\mathrm{NaCl}$ used here [6]. However, species tolerant to other salts are also tolerant to $\mathrm{NaCl}$ or vice versa [21]. For example, Branchinecta sandiegonensis Fugate, 1993 and Streptocephalus woottoni Eng, Belk and Eriksen, 1990 which are generally found in dilute coastal vernal pools, are strong hyperregulators when external $\mathrm{Na}^{+}$levels are below $60 \mathrm{mmol}^{-1}$ or under conditions of alkalinities up to $0.8-1.0 \mathrm{~g} \mathrm{l}^{-1}$ [22]. Among anostracans, Artemia spp. are both hypo-and hyperosmotic regulators. For example, Artemia franciscana Kellog, 1906 showed little variations in haemolymph ion concentrations when the external salinity (as $\mathrm{NaCl}$ ) was $<0.3 \mathrm{~g} \mathrm{l}^{-}$ 1 to supersaturated levels. However, this capacity has been reduced when exposed to low $\mathrm{pH}$ conditions [23]. Therefore it appears unlikely that $B$. schaefferi in natural ponds tolerates salinity levels higher than $8 \mathrm{~g} / \mathrm{l}$, especially under low $\mathrm{pH}$ conditions.

\section{Conclusion}

B. schaefferi which inhabits temporary freshwater ponds tolerated only low $\mathrm{NaCl}$ levels. When raised on Chlorella at a density of $1 \times 10^{6}$ cells $/ \mathrm{ml}$ under $0 \mathrm{~g} / \mathrm{l}$ of NaCl concentration, both males and females had similar lifespan. However, when the salinity of the medium was increased from 0 to $8 \mathrm{~g} / \mathrm{l}$, both survival and reproduction were decreased. $\mathrm{NaCl}$ as low as $1 \mathrm{~g} / \mathrm{l}$ caused negative influence on the life expectancy at birth, gross and net reproductive rates as well as the rate of population increase. Thus the low tolerance to salinity of this species suggests that it is 
unlikely to colonize inland saline waterbodies. Even in those freshwater ponds where it is found, anthropogenic factors leading to elevated salinity may eventually dislodge this species from its natural habitat [24]. In Germany $B$. schaefferi is considered as one of the most endangered crustacean species. Therefore, the temporary ponds in which it is found, proper conservative measures must be taken to protect this species.

\section{Methods}

\section{Culture of test species}

The original parental stock of Branchipus schaefferi was obtained from Boughzoul, Algeria and mass cultured using Scenedesmus. Cyst collection was done according to methods described previously [13]. Cysts were hatched following Ali et al. [17]. From the naupliar stage until the termination of the experiments, we used the single-celled alga Chlorella vulgaris. C. vulgaris (Strain CL-V-3, CICESE, Ensenada, Baja California, Mexico) was mass cultured using Bold's basal medium [25]. Based on a preliminary study, we selected $1.0 \times 10^{6}$ cells/ ml of Chlorella as the food density. Analytical grade sodium chloride was used for preparing different salinity levels. For cyst hatching, maintaining B. schaefferi in cultures or for experiments we used reconstituted moderately hard water (the EPA medium) [26] as the medium, which was prepared by dissolving $0.9 \mathrm{~g}$ of $\mathrm{NaHCO}_{3}, 0.6 \mathrm{~g}$ of $\mathrm{CaSO}_{4}, 0.6 \mathrm{~g}$ of $\mathrm{MgSO}_{4}$ and $0.04 \mathrm{~g}$ of $\mathrm{KCl}$ per litre of distilled water.

\section{Experimental design}

Based on a preliminary study, five nominal concentrations of $\mathrm{NaCl}(0,1,2,4$ and $8 \mathrm{~g} / \mathrm{l})$ chosen. From a stock solution of $32 \mathrm{~g} / \mathrm{l}$, the desired concentrations were prepared through serial dilution using EPA medium. The effect of dilution on the algal density while preparing different salinity levels were considered and accordingly adjustments were done so as to obtain the final algal density of $1.0 \times 10^{6}$ cells $/ \mathrm{ml}$. The general test conditions were: fluorescent illumination (2000 Lux) continuous and diffused; temperature $23 \pm 1{ }^{\circ} \mathrm{C}, \mathrm{pH}$ : 7.0-7.5, medium renewed completely after every $24 \mathrm{~h}$.

Fifty nauplii were introduced into each of the 5 salt concentrations with an algal density of $1.0 \times 10^{6}$ cells $/ \mathrm{ml}$ present in transparent test jars of $500 \mathrm{ml}$ and the medium was renewed daily. After 10 days, by which time it was possible to distinguish the sex [13], the juveniles were used for conducting life table demographic studies. Into each of the 15 (5 salt concentrations X 3 replicates) test jars containing $100 \mathrm{ml}$ medium we introduced one male and one female B. schaefferi (juveniles). Following initiation of the experiments, we counted the number of cysts from each test jar and the medium was renewed with appropriate salt level and algal density daily. If a male partner in a given test jar died then it was replaced by another one being grown simultaneously under similar conditions from the stock. Similarly if a female died then it was replaced by another female of similar test conditions, although the cyst count was not considered further [13]. The experiments were discontinued when every individual of the original pair died in each replicate. Based on the data collected, we derived age-specific survivorship $\left(l_{x}\right)$ and fecundity $\left(m_{x}\right)$ curves. The following formulae were used for obtaining life history variables [15]:

$l_{x}=$ Proportion of survivorship per day

$\mathrm{m}_{\mathrm{x}}=$ Proportion of offspring produced per female per day

Life expectancy : $e_{x}=\frac{T_{x}}{n_{x}}$

where, $T_{x}=$ number of individuals per day

$\mathrm{n}_{\mathrm{x}}=$ number of living individuals at the initiation and the age $\times$ (days)

Gross reproductive rate $=\sum_{0}^{\infty} m_{x}$

Net reproductive rate $R_{o}=\sum_{0}^{\infty} l_{x} \cdot m_{x}$

Generation time $: T=\frac{\sum l_{x} \cdot m_{x} \cdot x}{R_{o}}$

Rate of population increase, Euler-Lotka equation (solved iteratively and using jackknife method [27]):

$\sum_{x=w}^{n} e^{-r x} \cdot l_{x} \cdot m_{x}=1$

where $r=$ rate of population increase per day, $w=$ age at maturity (days)

Differences in the data on life history variables obtained under different salt concentrations were statistically evaluated using analysis of variance (one-way ANOVA) and Tukey's tests [28].

\section{Competing interests}

The author(s) declare that they have no competing interests.

\section{Authors' contributions}

SSSS: Idea, design, some part of data collection and interpretation and write up; participated sufficiently to be an author of this manuscript. 
LB: Culture, maintenance of organisms, some part of data analysis and interpretation; participated sufficiently to be an author of this manuscript.

SN: Some parts of data collection, analysis, interpretation and write up; participated sufficiently to be an author of this manuscript.

GCM: Some parts of data collection, interpretation and write up; participated sufficiently to be an author of this manuscript.

KTB: Some parts of data collection, interpretation and write up; participated sufficiently to be an author of this manuscript.

\section{Acknowledgements}

Two anonymous reviewers have greatly improved our manuscript. This study was supported by a project from the Mexican National Council for Science and Technology (CONACyT-4I786). Thanks are also due to Marcela Carmarillo Ortiz (Head Librarian, UNAM Campus Iztacala) for bibliographic search.

\section{References}

I. Dumont H, Negrea S: Introduction to the Class Branchiopoda. Guides to the Identification of the Microinvertebrates of the Continental Waters of the World Backhuys Publishers, The Netherlands; 2002.

2. Williams DD: The ecology of temporary waters Croom Helm. London/ Sidney, Timber Press, Oregon; 1987.

3. Broch ES: Osmoregulatory patterns of adaptation to inland astatic waters by two species of fairy shrimps, Branchinecta gigas Lynch and Branchinecta mackini Dexter. Journal of Crustacean Biology 1988, 8:383-391.

4. Geddes MC: Seasonal fauna of some ephemeral saline waters in western Victoria with particular reference to Parartemia zietziana Sayce (Crustacea: Anostraca). Aust J Mar Freshwater Res 1976, 27:I-22.

5. Dodson SI, Frey DG: Cladocera and other branchiopoda. In Ecology and classification of North American freshwater invertebrates Edited by: Thorp JH, Covich AP. Academic Press, London; 2001:850-914.

6. Williams WD: Salinity as a determinant of the structure of biological communities in salt lakes. Hydrobiologia 1998, 381:191-201.

7. Peredo-Alvarez VM, Sarma SSS, Nandini S: Combined effect of concentrations of algal food (Chlorella vulgaris) and salt (sodium chloride) on the population growth of Brachionus calyciflorus and Brachionus patulus (Rotifera). Rev Biol Trop 2003, 5 I:399-408.

8. Lynch M: The evolution of cladoceran life histories. Quarterly Reviews of Biology 1980, 55:23-42.

9. Forbes VE, Calow $P$ : Is the per capita rate of increase a good measure of population-level effects in ecotoxicology? Environ Toxicol Chem 1999, I 8: I544-I556.

10. Baxevanis AD, El-Bermawi N, Abatzopoulos TJ, Sorgeloos P: Salinity effects on maturation, reproductive and life span characteristics of four Egyptian Artemia populations (International Study on Artemia. LXVIII). Hydrobiologia 2004, 5 I 3:87-I00.

II. Maier G, Hoessler J, Tessenow U: Succession of physical and chemical conditions and of crustacean communities in some small, man-made, water bodies. Int Rev Hydrobiol 1998, 83:405-4I8.

12. Beladjal L, Peiren N, Dierckens KR, Mertens J: Feeding strategy of two sympatric anostracan species (Crustacea). Hydrobiologia 1997, 359:207-2I 2.

13. Beladjal L, Peiren N, Vendekerckhove TTM, Mertens J: Different life histories of the co-occurring fairy shrimps Branchipus schaefferi and Streptocephalus torvicornis. J Crust Biol 2003, 23:300-307.
14. Anaya-Soto A, Sarma SSS, Nandini S: Longevity of the freshwater anostracan Streptocephalus mackini (Crustacea: Anostraca) in relation to food (Chlorella vulgaris) concentration. Freshwater Biol 2003, 48:432-439.

15. Krebs CJ: Ecology; the experimental analysis of distribution and abundance Harper \& Row, New York; 1985.

16. Nandini S, Sarma SSS: ifetable demography of four cladoceran species in relation to algal food (Chlorella vulgaris L) density. Hydrobiologia 2000, 435: I17-126.

17. Ali AJ, Sarma SSS, Dumont HJ: Cyst production in the fairy shrimp, Streptocephalus proboscideus (Anostraca) in relation to algal and loricated rotifer diet. Crustaceana 1999, 72:5।7-530.

18. Nandini S, Sarma SSS: Population growth of some genera of cladocerans (Cladocera) in relation to algal food (Chlorella vulgaris) levels. Hydrobiologia 2003, 49 I:2। I-219.

19. Sarma SSS, Nandini S, Gulati RD: Life history strategies of cladocerans: comparisons of tropical and temperate taxa. Hydrobiologia 2005, 542:315-333.

20. King CE: The evolution of lifespan. In Evolution and genetics of life histories Edited by: Dingle H, Hegmann JP. Springer Verlag, New York; 1982:121-128.

21. Sarma SSS, Elguea-Sánchez B, Nandini S: Effect of salinity on competition between the rotifers Brachionus rotundiformis Tschugunoff and Hexarthra jenkinae (De Beauchamp) (Rotifera). Hydrobiologia 2002, 474: 183-188.

22. Gonzalez RJ, Drazen J, Hathaway S, Bauer B, Simovich M: Physiological correlates of water chemistry requirements in fairy shrimps (Anostraca) from southern California. J Crust Biol 1996, 16:315-322.

23. Doyle JE, McMahon BR: Effects of acid exposure in the brine shrimp Artemia franciscana during development in seawater. Comparative Biochemistry and Physiology 1995, I I 2A: I 23-I 29.

24. Maier G: The status of large branchiopods (Anostraca: Notostraca, Conchostraca) in Germany. Limnologica 1998, 28:223-228

25. Borowitzka MA, Borowitzka LJ: Micro-algal biotechnology Cambridge University Press, United Kingdom; 1988.

26. Weber Cl: Methods for measuring the acute toxicity of effluents and receiving waters to freshwater and marine organisms United States Environmental Protection Agency, Cincinnati, Ohio; 1993.

27. Meyer JS, Ingersoll CG, McDonald LL, Boyce MS: Estimating uncertainty in population growth rates: Jackknife vs bootstrap techniques. Ecology 1986, 67: I I56-1 I66.

28. Zar JH: Biostatistical analysis Pearson Education Pvt. Limited, Singapore; 2003.

\section{Publish with Biomed Central and every scientist can read your work free of charge}

"BioMed Central will be the most significant development for disseminating the results of biomedical research in our lifetime. "

Sir Paul Nurse, Cancer Research UK

Your research papers will be:

- available free of charge to the entire biomedical community

- peer reviewed and published immediately upon acceptance

- cited in PubMed and archived on PubMed Central

- yours - you keep the copyright

Submit your manuscript here:

http://www.biomedcentral.com/info/publishing_adv.asp
BioMedcentral 